\title{
Therapeutic Landscape as a Healthcare Facility in Egypt: Design and Evaluation Process
}

\author{
Mahmoud Ahmed Zaki ${ }^{1}$, Shahira Sharaf Eldin ${ }^{2}$, Hosny Ahmed Dewer ${ }^{3}$, \\ Alaa Zeinelabedin Abdelhafeez ${ }^{*}$ \\ 1,2 Professor, Department of Architecture, Tanta University, Tanta, Egypt \\ ${ }^{3}$ Lecturer, Department of Architecture, Tanta University, Tanta, Egypt \\ ${ }^{4}$ Master Student, Department of Architecture, Tanta University, Tanta, Egypt \\ *Corresponding author: alaazein01@gmail.com
}

\begin{abstract}
Outdoor natural environments are well proven to have psychological, physical, and social benefits, particularly those attached to healthcare facilities. Despite that, the Egyptian Codes devoid of data related to the design of such gardens, which hinders the design process and the inclusion of these spaces within health care facilities. Thus, this paper seeks to reach a set of considerations for the design of different types of therapeutic gardens by summarizing the findings and recommendations of some evidence-based design (EBD) research and post-occupancy evaluations (POEs). Post-occupancy evaluations lack to determining the percentage of achieving the design principles in the garden. Therefore, in addition to the behavioral and visual observations to evaluate Children's Cancer Hospital garden in Egypt (CCHE), an audit tool was integrated to combine the advantages of audit tools and POEs. With this merging, we can reach a steady form of post-occupancy evaluations of pediatric cancer hospital's gardens to be a guide for future researches and landscape architects.
\end{abstract}

Keywords: Healing environments, Healthcare facilities, Healing gardens, Post-occupancy evaluation, Therapeutic gardens.

\section{Introduction}

Man has believed in the healing benefits of nature for those suffering from psychological and physical problems for thousands of years. The beginning of this belief was from the ancient Egyptian civilization through the early Asian, Greek, and Romanian, and then to the monastic monasteries in the middle Ages. This interest continued to the beginning of the twentieth century, and then it began to diminish as a result of the preference for functional efficiency and priority of financial gain. Now it being re-discovered in the form of healing landscapes and therapeutic gardens [1]-[5]. When access to nature became well-documented as an element of healing by growing evidence [6]-[11], the research concentrated on studying the design and evaluation process of therapeutic gardens. The American Horticultural Therapy Association (AHTA) has divided the natural environments that aid in the healing process into several different types, according to user groups and garden design programs. In Egypt, some of the therapeutic garden designs, when investigating, you hardly discover whether it serves frail elderly, psychiatric,
Alzheimer's, or cancer patients. Therefore, it mostly does not meet all (psychological, physical, and social) needs of all users (patients, visitors, or staff).

Due to the varied types of therapeutic gardens and the different needs of users, it was necessary to identify design criteria that are in line with this difference to increase the effectiveness of these gardens. The various design guidelines were summarized from the results of experimental researches and surveys for gardens attached to different types of hospitals and health care facilities. These results defined decisions for designers to access the highest possible health outcomes and to obtain a base of design guidelines that assist in the evaluation processes.

\section{Methodology}

\section{A. Theoretical Study}

Although the terms (healing gardens, therapeutic gardens, and horticultural therapy gardens) intended to improve health outcomes through spending time in, the American Horticultural Therapy Association developed definitions that explain the difference between them Table 1 [12].

Table 1

Definitions of some different types of gardens according to AHTA

\begin{tabular}{|l|l|}
\hline Gardens Types & \multicolumn{1}{|c|}{ Definitions according to (AHTA) } \\
gealing & $\begin{array}{l}\text { "Healing gardens are natural environments } \\
\text { associated with public hospitals and have positive } \\
\text { effects on all users, regardless of the type of } \\
\text { disability. It can also be classified into } \\
\text { subcategories as horticultural or therapeutic } \\
\text { gardens." }\end{array}$ \\
\hline $\begin{array}{l}\text { Therapeutic } \\
\text { gardens (field } \\
\text { of study) }\end{array}$ & $\begin{array}{l}\text { "Therapeutic gardens serve specific users (patients } \\
\text { with Alzheimer, cancer patients, frail elderly, etc.) } \\
\text { and meet their needs. These gardens can be } \\
\text { considered as a part of the healing gardens or an } \\
\text { indoor rehabilitation area extension." }\end{array}$ \\
\hline $\begin{array}{l}\text { Horticultural } \\
\text { therapy } \\
\text { gardens }\end{array}$ & $\begin{array}{l}\text { "Horticultural therapy gardens also are a } \\
\text { subcategory of therapeutic gardens with unique } \\
\text { characteristics, it designed specifically for the use } \\
\text { of patients in the care and cultivation of plants as } \\
\text { part of a treatment program, the thing that } \\
\text { stimulates patients to move and strengthen their } \\
\text { muscles." }\end{array}$ \\
\hline
\end{tabular}




\section{B. Analytical Study}

Whereas the therapeutic gardens are healing gardens but more specialized and interest in a certain category of patients, the design considerations were divided into general and specific.

\section{1) General design considerations}

According to Cooper Marcos [2], the general design guidelines are organized in three sections Table 2:

- Planning process considerations:

Considerations relating to the site and buildings in addition to the outdoor spaces, and it should be taken into account from the planning process of the project before the beginning of the outer space design.

\section{- Comprehensive design considerations:}

Applicable to all components of outdoor spaces in all facilities (whether health care facilities or others) for example, safety, security, and privacy.

\section{- Considerations of the physical elements of all healing} gardens:

These considerations apply to physical components within all outdoor spaces attached to health care facilities as paths, seating, planting, and the like.

2) Specific design considerations

In addition to the general design considerations that must be fulfilled in all healing gardens, there are special considerations that distinguish a therapeutic garden from another or emphasize to achieve them in one garden without the other. In Table 3 some types of these gardens and their considerations, such as Alzheimer's [22], [2], [23], [24], the elderly [23], [2], [25], cancer [26], [27], mental [28], [22], [29], children [30], [31], [32].

\section{Applied Study}

Post-occupancy evaluations (POEs) have proven to be very effective in assessing outdoor spaces, regardless if these gardens were therapeutic or not [33]. POEs also gives an overview of the shortcomings and successes in the garden, show who uses it and why, the number of garden visits, different activities, barriers to the visit, and user satisfaction with the garden. However, it lacks a list of elements and qualities that should ideally be incorporated into a therapeutic garden to assess the quality of design considerations implementation from the user perspective and whether it meets

Table 2

General design considerations

\begin{tabular}{|c|c|c|}
\hline Planning process considerations [2] & $\begin{array}{c}\text { Comprehensive considerations } \\
{[10],[2],[13],[14][15],[16],[17]}\end{array}$ & $\begin{array}{l}\text { Considerations for the physical elements of all healing gardens } \\
{[[2],[18],[19],[20],[21],[13],[14],[15],[16]}\end{array}$ \\
\hline
\end{tabular}


minimum standards (audit tool). Therefore, we developed the POE for (CCHE) garden to include questionnaires in the form of an audit tool to be a combination of the advantages of POEs and audit tools. The European Landscape Convention described the landscape as "an area, perceived by people, whose character is the result of the action and interaction of natural and human factors" [34]. Thus, the research method is based on four main criteria (site, users, operations, and evaluation of the garden). This research was based on (visual analysis, behavioral observation, and questionnaires) as tools for data collection, evaluation, and auditing Fig.1.

Table 3

Specific design considerations

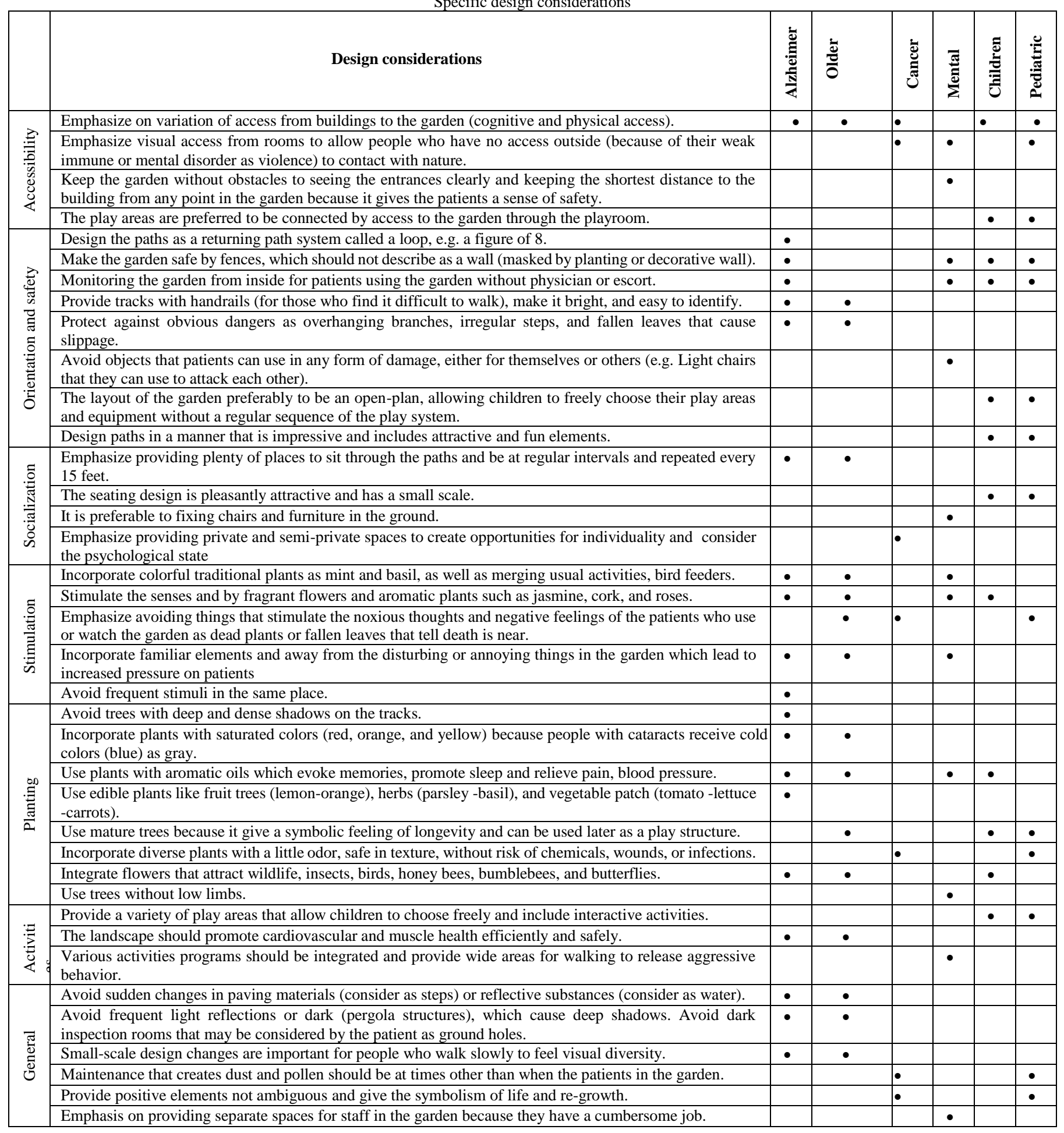




\section{1) Evaluation criteria}

- Site:

The site was examined through (geographical and physical analysis). The geographical analysis was conducted by visual analysis to studying the location, climate orientation, visibility and accessibility, the ratio of street width or open space to the building height, and entrances to the garden. The physical examination includes all hard elements in the garden as plants and structures that make up the garden and its various distinct areas Fig.2.

\section{- User and participants:}

Random samples participated in the research, whether from patients (inpatient, outpatient, surgical, or intensive care) or staff (doctors, nurses, physicians, and administrators).

- Operations (uses and activities):

The user's interaction with the garden happens through a group of activities (walking, eating, and passing through) that we monitored in the behavior matrix table 4 . The uses of the garden were determined by observation and drawing behavioral maps that used to track the circulations of user groups while using the garden.

- Evaluation of the garden:

The evaluation was at three points (1) Achieving general design considerations. (2) Achieving specific design considerations. (3) The degree of user satisfaction.

2) Evaluation tools:

- Visual analysis:

It provides an understanding of the physical, geographical conditions, and spatial proportions of the environment. It was conducted during the period from November 2018 until August 2019.

\section{- Behavioral observation:}

In the behavior observation data collected through on-site observation by the researcher for a week to know the user groups in the garden and drawing behavior mapping through which we can determine general use distribution and most distinct places in the garden for patients, visitors, and staff.

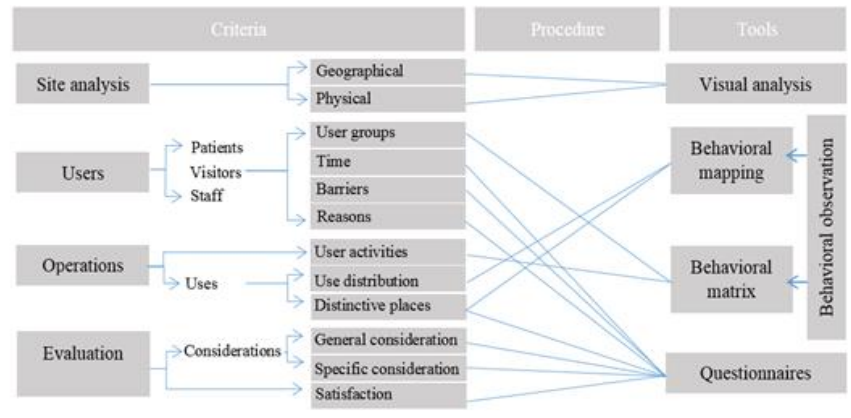

Fig. 1. Research methodology to evaluating therapeutic gardens by researcher

\section{- $\quad$ Survey (Questionnaires):}

The questionnaire was divided into four sets of questions. In the first group, the respondents were asked about number of visits, duration of visitation, reasons for visiting the garden, and obstacles that prevent them from the visit. In the second and third set, respondents were asked about the garden's achievement of general and specific design considerations. The degree of satisfaction was calculated by a scale of ten degrees, to assess the user satisfaction with the garden features.

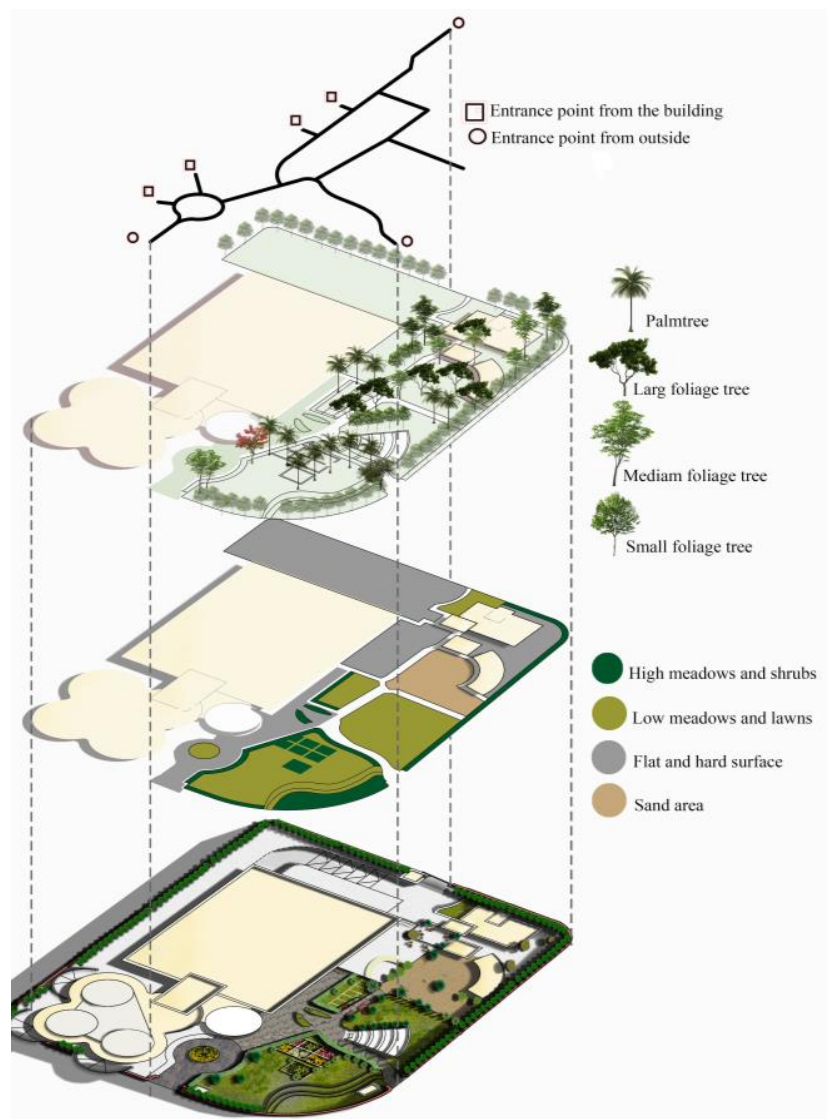

Fig. 2. Physical analysis for (CCHE) hospital's garden by researcher

\section{Results and Discussion}

\section{A. Site Analysis}

The hospital is located in the area of Qasr Al-Aini, Cairo. The site has a quiet location as it has no sources of noise. The site is easy to access as it can be reached through four main streets and linked to three points of road intersection (nodes) make it easier to access. Furthermore, the hospital has a distinctive design form that makes it visible from nearby and surrounding places. The ratio of outdoor building heights to the street width is approximately $1: 2$, which consider as an appropriate ratio to create an opportunity for privacy within the garden.

\section{B. User and Participants}

\section{1) User groups in the garden}

Table 4 shows the data of behavior observations in the form of a matrix to illustrate the information collected within a typical week period by watching the garden every day for ten minutes (from 11 to 11:10 AM), where 643 occupancy instances were monitored during the research period (families, visitors, children, staff and patients with therapist) Fig. 3. 
2) Time that user spent in the garden

There are many observations about the time of using the garden, whether the frequency of the garden, the length of visitation, or the time of the day users prefer to visit the garden. This information was collected through the questionnaires, which included 51 responses 16 of the staff and 35 were nonstaff (visitors and patients) Fig. 4, Fig. 5, and Fig. 6.

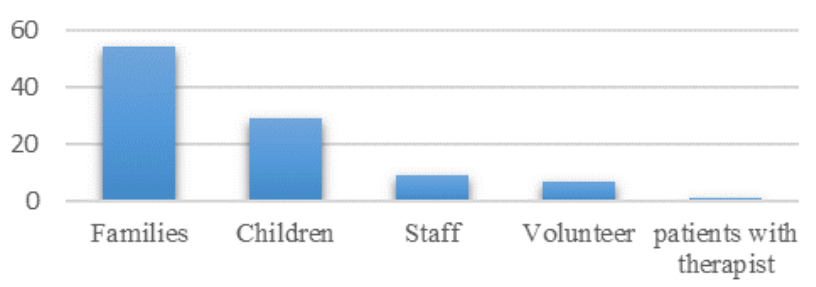

Fig. 3. User groups in the garden

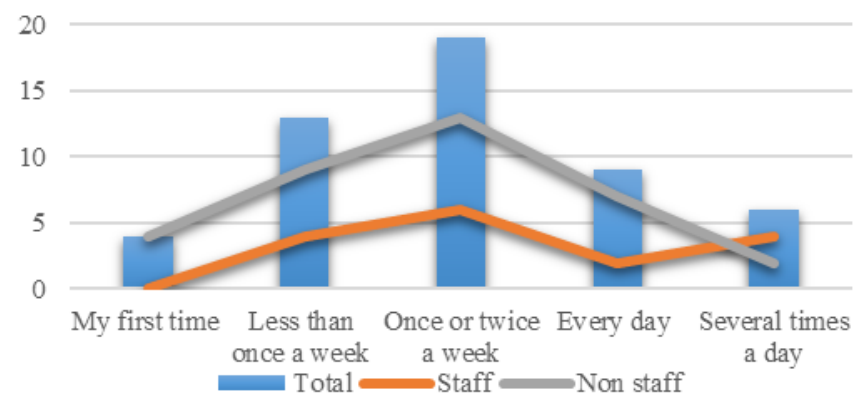

Fig. 4. Frequency of the garden

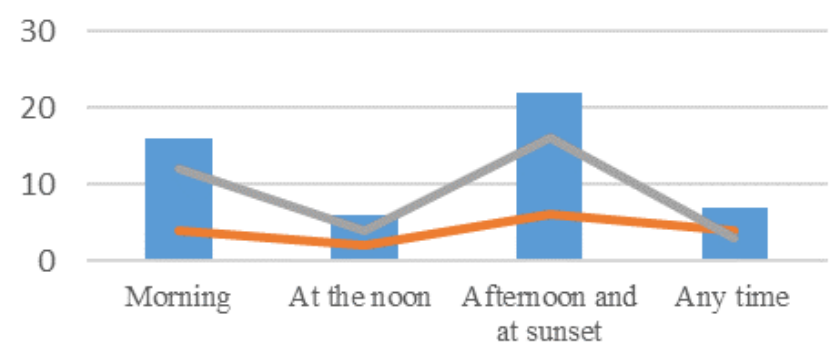

Total $\longrightarrow$ Staff $=$ Non staff

Fig. 5. Time of the day users prefer to visit the garden

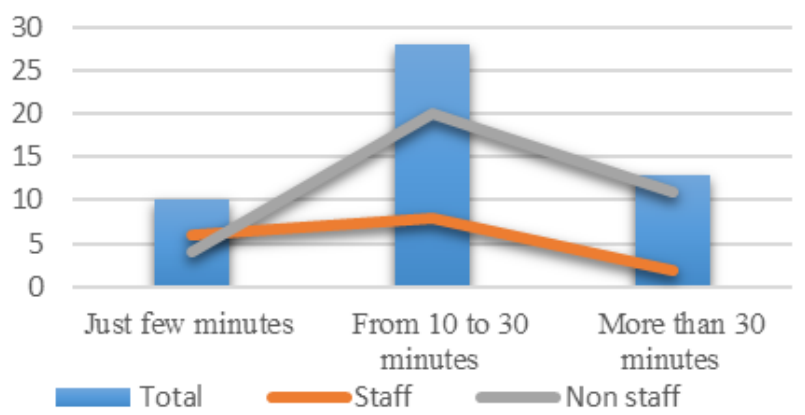

Fig. 6. Length of visitation

Among the questions that were asked to the respondents were: What is the obstacles and reasons for garden visitation? Fig. 7, and Fig. 8.

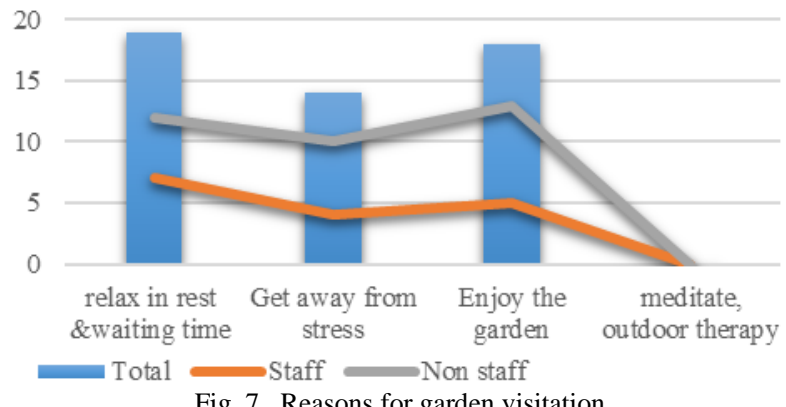

Fig. 7. Reasons for garden visitation

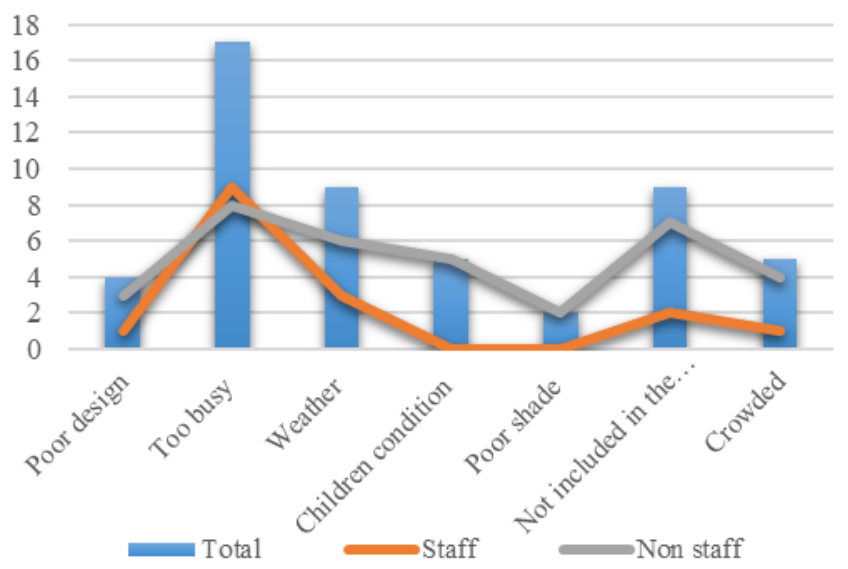

Fig. 8. Obstacles for garden visitation

\section{Operations}

\section{1) Activities}

From the behavior matrix, it is possible to determine what users do in the garden from a group of activities were counted within a week of field observation Table 4; Fig. 9.

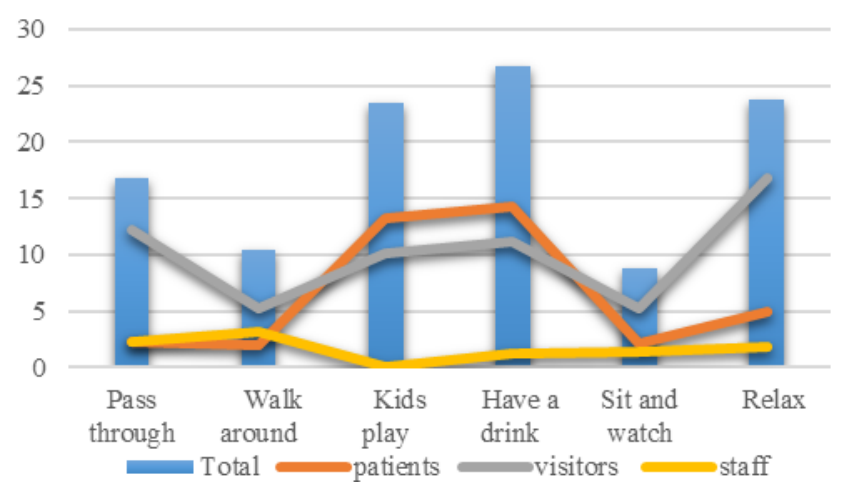

Fig. 9. Activities in the garden

2) Uses

- Use distribution:

Fig. 10, Fig. 11, and Fig. 12 illustrate graphics usage patterns that explain the shape of the garden use. The garden is monitored from a point in its middle so as to allow the observer to detect all the garden and monitor the users from the beginning of their entry to the garden until they exit. By comparing the motion path for both visitors and patients, both are almost identical where patients or visitors leave the hospital 
heading to the play area or sitting area near it. This tour may interrupt by heading to the cafeteria and then returning to the play or sitting area again. The path of the staff is different where the workers using the garden either to pass through or to reach the cafeteria.

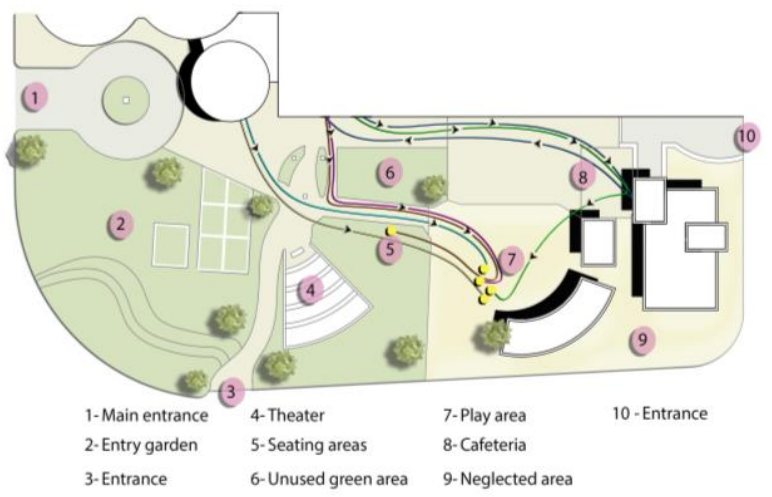

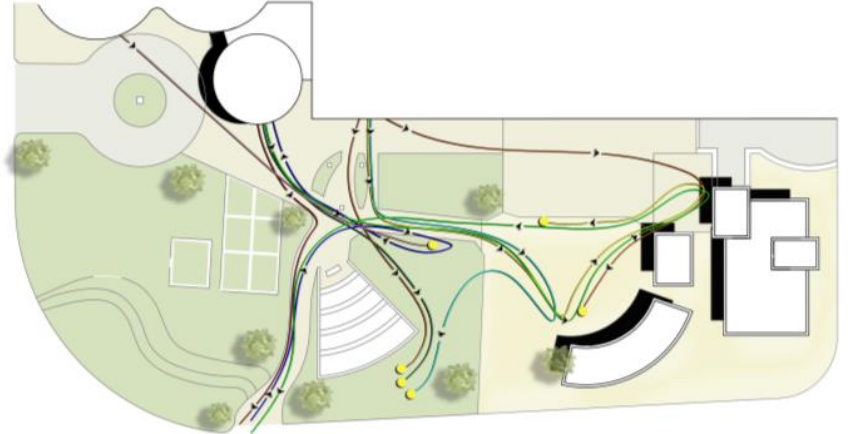

Fig. 11. Usage patterns for visitors by researcher

Fig. 10. Usage patterns for patients by researcher

The behavioral mapping matrix

Location: The Children's Cancer Hospital Egypt (CCHE 57357)

Date from 29-6-2019 to 5-7-2019

Table 4

Duration of observation every day: 10 minutes.

Behavior matrix

\begin{tabular}{|c|c|c|c|c|c|c|c|c|c|c|c|c|c|c|c|c|c|c|c|c|c|}
\hline \multirow{3}{*}{ Category } & \multicolumn{14}{|c|}{ Visitors } & \multirow{2}{*}{\multicolumn{7}{|c|}{\begin{tabular}{|c|} 
Patient \\
Kids /Teen
\end{tabular}}} \\
\hline & \multicolumn{7}{|c|}{ Family } & \multicolumn{7}{|c|}{ Volunteer } & & & & & & & \\
\hline & 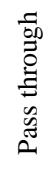 & 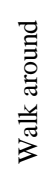 & 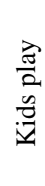 & 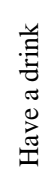 & 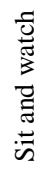 & $\frac{\mathfrak{J}}{\mathscr{e}}$ & 苟 & 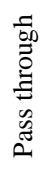 & 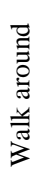 & $\begin{array}{l}\frac{\vec{a}}{2} \\
\frac{a}{2} \\
\frac{a}{2}\end{array}$ & $\begin{array}{l}\text { 首 } \\
\tilde{\sigma} \\
\tilde{D} \\
\tilde{J} \\
\vec{J}\end{array}$ & 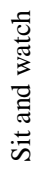 & 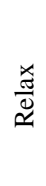 & 沓 & 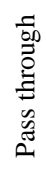 & 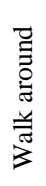 & $\begin{array}{l}\frac{\vec{a}}{2} \\
\frac{0}{0} \\
\frac{0}{2}\end{array}$ & 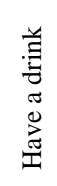 & 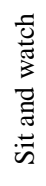 & 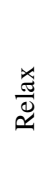 & 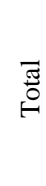 \\
\hline $29-6-2019$ & 6 & 3 & 7 & 9 & 4 & 16 & 45 & 2 & 0 & 0 & 1 & 1 & 0 & 4 & 2 & 3 & 10 & 4 & 1 & 3 & 23 \\
\hline $30-6-2019$ & 10 & 6 & 9 & 8 & 5 & 18 & 56 & 4 & 0 & 0 & 3 & 1 & 0 & 8 & 3 & 1 & 13 & 3 & 3 & 5 & 28 \\
\hline $1-7-2019$ & 8 & 3 & 6 & 1 & 4 & 15 & 47 & 3 & 0 & 0 & 2 & 0 & 0 & 5 & 4 & 4 & 9 & 5 & 0 & 4 & 26 \\
\hline $2-7-2019$ & 5 & 3 & 8 & 7 & 6 & 11 & 40 & 3 & 0 & 0 & 0 & 0 & 0 & 3 & 1 & 2 & 15 & 4 & 2 & 5 & 29 \\
\hline 3-7-2019 & 9 & 3 & 7 & 11 & 3 & 13 & 46 & 2 & 0 & 2 & 0 & 1 & 0 & 5 & 2 & 1 & 11 & 4 & 1 & 6 & 25 \\
\hline $4-7-2019$ & 11 & 6 & 8 & 9 & 2 & 16 & 52 & 5 & 0 & 0 & 1 & 0 & 0 & 6 & 2 & 0 & 10 & 3 & 3 & 5 & 23 \\
\hline $5-7-2019$ & 7 & 10 & 12 & 8 & 6 & 18 & 61 & 3 & 0 & 6 & 2 & 1 & 1 & 13 & 1 & 2 & 16 & 6 & 4 & 4 & 33 \\
\hline Total & \multicolumn{7}{|c|}{347} & \multicolumn{7}{|c|}{44} & \multicolumn{7}{|c|}{187} \\
\hline Percentage & \multicolumn{7}{|c|}{$54.1 \%$} & \multicolumn{7}{|c|}{$6.9 \%$} & \multicolumn{7}{|c|}{$29.1 \%$} \\
\hline
\end{tabular}

\begin{tabular}{|c|c|c|c|c|c|c|c|c|c|c|c|c|c|c|c|}
\hline \multirow[b]{2}{*}{ Category } & \multicolumn{14}{|c|}{ Staff } & \multirow[b]{3}{*}{ 芯 } \\
\hline & \multicolumn{7}{|c|}{ Staff } & \multicolumn{7}{|c|}{ Staff with kids } & \\
\hline ڤે & 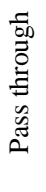 & 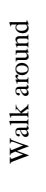 & $\begin{array}{l}\frac{\lambda}{a} \\
\frac{a}{a} \\
\frac{0}{0}\end{array}$ & 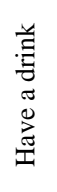 & 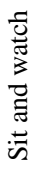 & 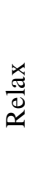 & 氶 & 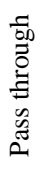 & 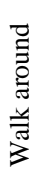 & $\begin{array}{l}\frac{\vec{d}}{2} \\
\frac{0}{2} \\
\frac{0}{2}\end{array}$ & 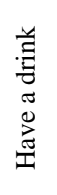 & 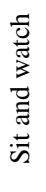 & $\frac{\stackrel{a}{a}}{\mathscr{Q}}$ & 胥 & \\
\hline 29-6-2019 & 1 & 2 & 0 & 1 & 2 & 3 & 9 & 1 & 0 & 0 & 0 & 0 & 0 & 1 & 82 \\
\hline 30-6-2019 & 3 & 4 & 0 & 1 & 1 & 2 & 11 & 0 & 0 & 0 & 0 & 0 & 0 & 0 & 103 \\
\hline $1-7-2019$ & 1 & 3 & 0 & 3 & 2 & 1 & 10 & 1 & 1 & 0 & 0 & 0 & 0 & 2 & 90 \\
\hline $2-7-2019$ & 0 & 4 & 0 & 0 & 2 & 0 & 6 & 0 & 0 & 0 & 0 & 0 & 0 & 0 & 78 \\
\hline $3-7-2019$ & 2 & 1 & 0 & 1 & 1 & 3 & 8 & 0 & 0 & 0 & 0 & 0 & 0 & 0 & 84 \\
\hline 4-7-2019 & 4 & 2 & 0 & 2 & 1 & 1 & 10 & 1 & 0 & 0 & 0 & 0 & 0 & 1 & 92 \\
\hline $5-7-2019$ & 0 & 2 & 0 & 0 & 0 & 2 & 4 & 1 & 11 & 0 & 0 & 0 & 0 & 2 & 113 \\
\hline Total & \multicolumn{7}{|c|}{58} & \multicolumn{7}{|c|}{0} & 642 \\
\hline Percentage & \multicolumn{7}{|c|}{$9.03 \%$} & \multicolumn{7}{|c|}{$.94 \%$} & \\
\hline
\end{tabular}




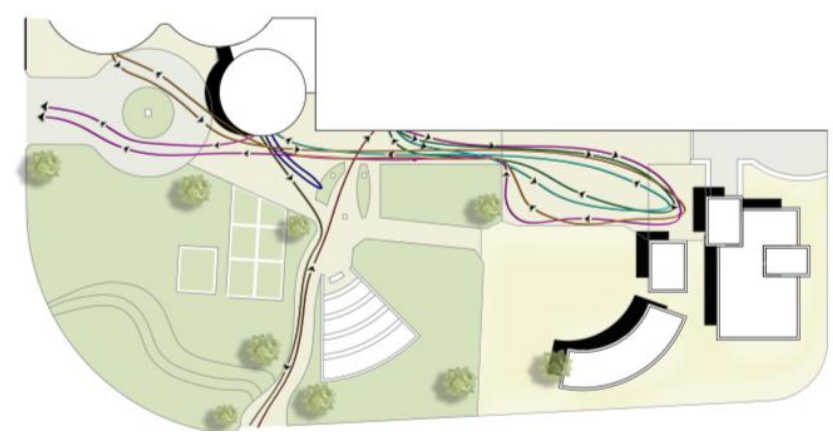

Fig. 12. Usage patterns for staff by researcher

\section{A. Evaluation of the Garden (Audit Tool)}

1) Achieving general design considerations

Table 5

A questionnaire of the planning process considerations. This questionnaire is for the designers participating in the design of the garden understudy Planning process considerations

Is the garden designed based on the evidence-based design approach?

The design respects all garden users (patients, visitors, and staff).

The organizational structure of the institution, the cultures, and the policies used were considered in the design.

All stakeholders were involved in the design process.

Functional, physical, and programmatic requirements formed the basis for how to garden was designed.

There is a major source of funding, from the design process to periodic maintenance.

The garden was designed by an interdisciplinary design team (IDT) including landscape designers.

If the garden was planned by a team of landscape designers, were they trained to design therapeutic gardens?

As a garden for a pediatric cancer hospital, does the design team include the appropriate professionals to design this type of garden as (occupational, physical, other professional therapists)?

Components of the overall environment of care EOC (concepts, people, systems, layout, operations, and implementation) are generally

considered a healthy environment.

Table 6

A questionnaire of the comprehensive design considerations. This questionnaire is for groups of users from patients, visitors, and staff.

\begin{tabular}{|c|c|c|c|c|c|c|}
\hline Comprehensive design considerations & Excellent & Good & Fair & Poor & Mean & Level \\
\hline Giving the opportunity to choose between different areas in the garden. & 9 & 18 & 21 & 3 & 2.65 & Good \\
\hline Promoting the idea of privacy in the garden by providing isolated places. & 2 & 8 & 7 & 34 & 1.57 & Poor \\
\hline $\begin{array}{l}\text { Encouraging social support and communication between users and provide features that } \\
\text { stimulate it. }\end{array}$ & 23 & 16 & 8 & 4 & 3.14 & Good \\
\hline Access to nature and positive distraction. & 17 & 26 & 4 & 4 & 3.09 & Good \\
\hline Visibility of the garden (visual access) from all parts of the hospital. & 11 & 14 & 21 & 5 & 2.61 & Good \\
\hline $\begin{array}{l}\text { Access to the garden (physical access) from all parts of the hospital, especially for people with } \\
\text { disabilities and wheelchair users. }\end{array}$ & 9 & 29 & 10 & 3 & 2.86 & Good \\
\hline Garden environment is an aesthetic environment and help to relax. & 15 & 30 & 6 & 0 & 3.18 & Good \\
\hline $\begin{array}{l}\text { The design supports the physical and emotional comfort of users (the availability of shaded } \\
\text { areas, or comfortable furniture). }\end{array}$ & 20 & 19 & 7 & 5 & 3.06 & Good \\
\hline The garden is quiet and minimizes negative factors and external interventions as urban noise. & 26 & 19 & 5 & 1 & 3.37 & Excellent \\
\hline The simplicity of the garden design idea and avoiding ambiguous symbols in its elements. & 35 & 13 & 3 & 0 & 3.63 & Excellent \\
\hline $\begin{array}{l}\text { Maintenance of the garden and all its components and away from the damaged and broken } \\
\text { elements and dead plants that lead to a sense of lack of interest. }\end{array}$ & 16 & 27 & 4 & 4 & 3.08 & Good \\
\hline
\end{tabular}




\section{2) Achieving specific design considerations}

Table 7

A questionnaire of the considerations for the physical elements of all healing gardens. This questionnaire is for groups of users from patients, visitors, and staff

\begin{tabular}{|c|c|c|c|c|c|c|c|}
\hline & Considerations for the physical elements of all healing gardens. & Excellent & Good & Fair & Poor & Mean & Level \\
\hline \multirow{6}{*}{ 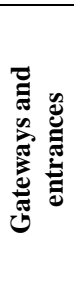 } & The number of entrances to the garden is sufficient. & 28 & 19 & 4 & 0 & 3.47 & Excellent \\
\hline & $\begin{array}{l}\text { The entrances are wide enough to accommodate people with special } \\
\text { transportation requirements. }\end{array}$ & 22 & 16 & 12 & 1 & 3.16 & Good \\
\hline & Seeing the garden from inside the building (e.g. glass doors). & 12 & 16 & 20 & 3 & 2.73 & Good \\
\hline & $\begin{array}{l}\text { The possibility of monitoring the garden from the inside by staff and } \\
\text { therapists. }\end{array}$ & 9 & 13 & 23 & 6 & 2.49 & Fair \\
\hline & The doors are easy in use (automatic or light), and visible. & 25 & 20 & 4 & 2 & 3.33 & Excellent \\
\hline & \multicolumn{5}{|l|}{ Total } & 3.04 & Good \\
\hline \multirow{5}{*}{ 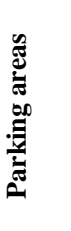 } & Distance between parking spaces and hospital entrances. & 25 & 14 & 9 & 3 & 3.20 & Good \\
\hline & Availability of parking lots and accommodating existing vehicles. & 9 & 17 & 17 & 8 & 2.53 & Good \\
\hline & $\begin{array}{l}\text { Clarity of the location of the parking and accessibility especially by patients } \\
\text { and visitors. }\end{array}$ & 24 & 16 & 11 & 0 & 3.26 & Excellent \\
\hline & $\begin{array}{l}\text { Vehicles (ambulance and cars for people with special needs) access to the } \\
\text { closest point to the entrance and emergency. }\end{array}$ & 34 & 12 & 5 & 0 & 3.57 & Excellent \\
\hline & \multicolumn{5}{|l|}{ Total } & 3.14 & Good \\
\hline \multirow{6}{*}{ 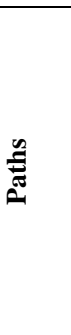 } & $\begin{array}{l}\text { Ease of navigation on tracks for pedestrians, people with disabilities, and } \\
\text { wheelchair users (Paving materials). }\end{array}$ & 14 & 26 & 8 & 3 & 3.00 & Good \\
\hline & $\begin{array}{l}\text { Organize paths (master paths, sub paths, and service paths) and do not } \\
\text { conflict with each other. }\end{array}$ & 9 & 14 & 20 & 8 & 2.47 & Fair \\
\hline & $\begin{array}{l}\text { The absence of obstacles that lead to slipping and stumbling motion or } \\
\text { cause obstruction to crutches and wheels. }\end{array}$ & 13 & 27 & 9 & 2 & 3.00 & Good \\
\hline & Width of tracks allows walking in groups. & 7 & 14 & 25 & 5 & 2.45 & Fair \\
\hline & $\begin{array}{l}\text { Provides frequent comfort points along the track with raised edges for } \\
\text { seating. }\end{array}$ & 16 & 18 & 11 & 6 & 2.86 & Good \\
\hline & \multicolumn{5}{|l|}{ Total } & 2.75 & Good \\
\hline \multirow{8}{*}{ 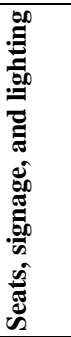 } & Seats are available in places where the user wants to use it. & 15 & 21 & 13 & 2 & 2.96 & Good \\
\hline & Seats in the garden help in physical comfort and help stand and sit. & 6 & 14 & 21 & 10 & 2.32 & Fair \\
\hline & Chairs are made of suitable material (don't retain heat or blur with the sun). & 17 & 20 & 12 & 2 & 3.02 & Good \\
\hline & Seats and chairs meet attractive views. & 4 & 13 & 15 & 19 & 2.04 & Fair \\
\hline & Availability of seating options (alone or in groups) through the distribution. & 3 & 11 & 17 & 20 & 1.94 & Fair \\
\hline & $\begin{array}{l}\text { Provide signs indicating the direction and parking places, entrances and } \\
\text { exits etc. }\end{array}$ & 8 & 16 & 20 & 7 & 2.49 & Fair \\
\hline & $\begin{array}{l}\text { Provides industrial lighting in the garden and distributed in different areas } \\
\text { to support the sense of safety and give a beautiful view of the place. }\end{array}$ & 22 & 16 & 13 & 0 & 3.18 & Good \\
\hline & \multicolumn{5}{|l|}{ Total } & 2.57 & Good \\
\hline \multirow{4}{*}{ 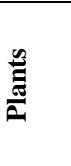 } & $\begin{array}{l}\text { The plants enhance feeling of the place, arouse emotion and provide a } \\
\text { positive distraction to the user. }\end{array}$ & 25 & 17 & 9 & 0 & 3.32 & Excellent \\
\hline & Access to plant and touch by people using wheelchairs. & 14 & 20 & 14 & 3 & 2.88 & Good \\
\hline & The types of plants used in the garden require frequent maintenance. & 11 & 15 & 20 & 5 & 2.63 & Good \\
\hline & \multicolumn{5}{|l|}{ Total } & 2.94 & Good \\
\hline
\end{tabular}


Table 8

A questionnaire of the specific design considerations for Children's cancer hospitals gardens. This questionnaire is for groups of users from patients, visitors, and staff

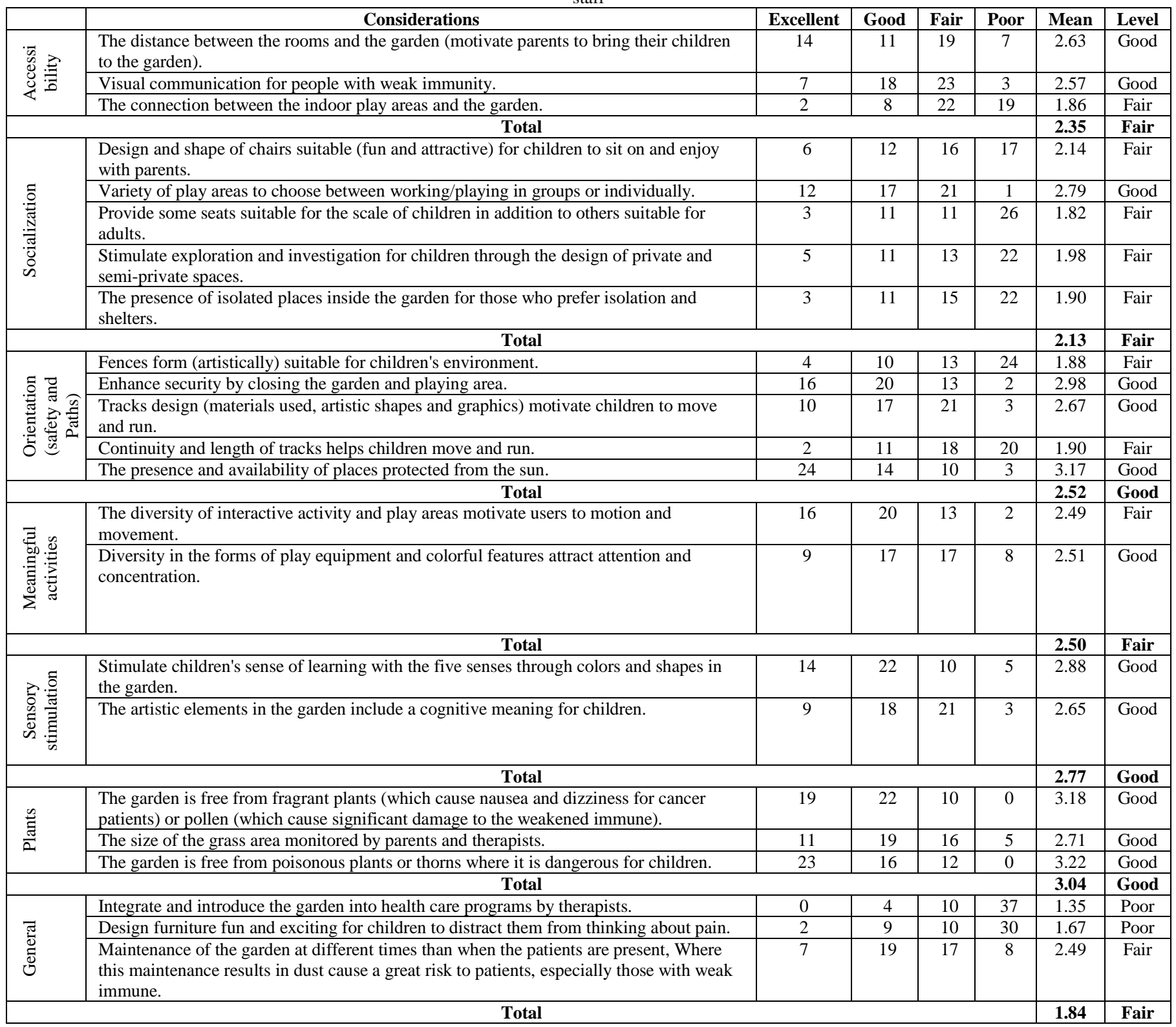

3) Degree of user satisfaction about features in the garden

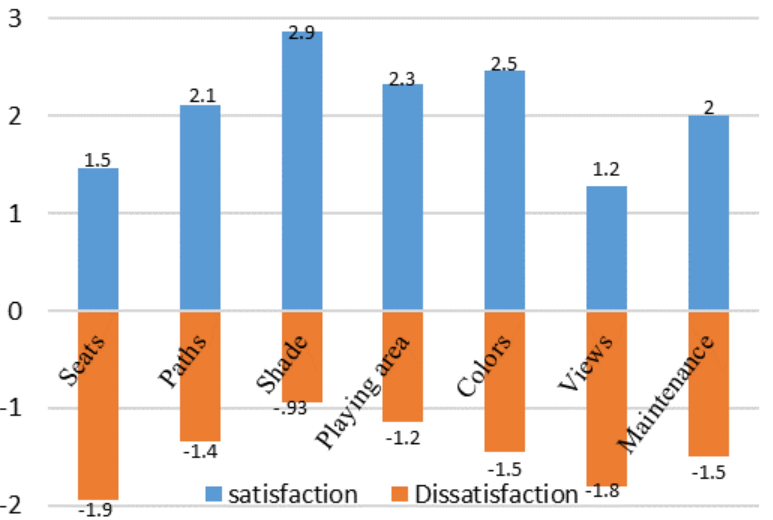

Fig. 13. User satisfaction about features
Respondents rated the garden's features by a 10-degrees scale. Fig. 13. represents the percentage of satisfaction and discontent for each feature separately in the garden.

\section{Conclusion}

The research aims to study the design of the different types of therapeutic gardens in Egypt and propose, (1) developing the Egyptian code to include the designing of outdoor environments as health care facilities. (2) The designer must take these gardens into account from the first stages of planning the project to reach the best possible results. (3) The necessity to differentiate between the types of these gardens. And raise the efficiency of the design elements depending on the needs of the user groups. (4) Incorporate the evaluation of these gardens 
into design approaches to increase design recommendations, thus assist in future research. (5) Developing the assessment to include general and specific design considerations in the form of an audit tool to combine how the garden is used and the extent to which design considerations are met. (6) Attempting to arrive at a consistent form for a comprehensive evaluation to be a reference for later designers. Finally, the evaluation can be used later as a starting point in the issuance of licensing certificates for such kind of gardens in Egypt to stop launching the concept of therapeutic gardens in any green area.

\section{References}

[1] P. L. Alt, "Sacred space and the healing journey," Ann. palliative. Med., vol. 6, no. 3, pp. 284-296, Jul. 2017.

[2] C. C. Marcus and N. A. Sachs, Therapeutic landscapes: An evidencebased approach to designing healing gardens and restorative outdoor spaces. Nashville, TN: John Wiley \& Sons, 2013.

[3] A. Annmarie, Medicine by design: the architect and the modern hospital. U of Minnesota Press, 2008.

[4] C. R. Horsburgh Jr, "Healing by design," N. Engl. J. Med., vol. 333, no. 11 , pp. 735-740, 1995

[5] R. S. Ulrich, "Influences of passive experiences with plants on individual well-being and health." The role of horticulture in human well-being and social development USA." pp. 93-105, 1992.

[6] T. Hartig, "Issues in restorative environments research: Matters of measurement," Psicología ambiental, pp. 41-66, 2011.

[7] A. E. Van Berg, S. L. Koole, and N. Y. Van Wulp, "Environmental preference and restoration: (How) are they related?" Journal of environmental psychology, vol. 23, no. 2, pp. 135-146, 2003.

[8] S. Rodiek, "Influence of an outdoor garden on mood and stress in older persons," Journal of Therapeutic Horticulture, vol. 13, no. 1, pp. 13-21, 2002.

[9] C. C. Marcus and M. Barnes, Eds., healing gardens: Therapeutic benefits and design recommendations, vol. 3. USA: John Wiley \& Sons, 1999.

[10] R. S. Ulrich, "Effects of gardens on health outcomes: theory and research," in Healing Gardens: Therapeutic Benefits and Design Recommendations.", New York, NY: John Wiley and Sons (WIE), 1999, pp. 27-86.

[11] R. Kaplan and S. Kaplan, The experience of nature: A psychological perspective. CUP Archive, 1989.

[12] E. R. Messer Diehl, "Definitions and Positions," American Horticultural Therapy Association, 2016. [Online]. Available: https://web.archive.org/web/20130908221648/http://ahta.org/sites/defaul t/files/DefinitionsandPositions.pdf. [Accessed: 14-Jan-2020].

[13] G. F. Yücel, "Hospital Outdoor Landscape Design," in Advances in Landscape Architecture, M. Özyavuz, Ed. London, England: Intech open, 2013, pp. 382-398.
[14] B. J. Anderson, "An exploration of the potential benefits of healing gardens on veterans with PTSD," Utah State University, Eng, 2011.

[15] D. Franklin, "How Hospital Gardens Help Patients Heal," Scientific American Magazine, 2012.

[16] M. Epstein, "Hospital gardens help patients heal," Seattle Daily Journal of Commerce Health Care Design \& Construction, vol. 11, 2006.

[17] Vapaa, "Healing Gardens: Creating places for restoration, meditation, and sanctuary", Ph.D. dissertation, Dept. Architecture, Virginia Tech, 2002.

[18] A. Shackell and R. Walter, "Greenspace design for health and wellbeing." Stockport, England: Forestry Commission, 2012.

[19] G. D. Kunders, Hospitals: Facilities Planning and Management. Tata McGraw-Hill Education, 2008.

[20] B. Main and G. G. Hannah, Site furnishings: a complete guide to the planning, selection and use of landscape furniture and amenities. John Wiley \& Sons, 2010.

[21] F. S. Verdeber and Refuerzo, Innovations in Hospice Architecture. Taylor \& Francis, 2006.

[22] T. J. Rivasseau et al., "Healing gardens and cognitive behavioral units in the management of Alzheimer's disease patients: The Nancy experience," Journal of Alzheimer's disease, vol. 34, no. 1, pp. 325-338, 2013.

[23] J. Zeisel, "Creating a therapeutic garden that works for people living with Alzheimer's," J. Hous. Elderly, vol. 21, no. 1-2, pp. 13-33, 2007.

[24] A. Pollock and M. Marshall, "Designing outdoor spaces for people with dementia," Nursing Older People, vol. 25, no. 7, 2013.

[25] M. B. Detweiler et al., "What is the evidence to support the use of therapeutic gardens for the elderly," Psychiatry Investig., vol. 9, no. 2, pp. 100-110, 2012.

[26] K. Busa, "The designer becomes the patient: fighting leukemia gave me a new perspective on healing gardens," Land sc. Archit. Mag, vol. 103, pp. 114-118, 2013.

[27] R. Valente and C. C. Marcus, "Giardini che guariscono: processi progettuali e realizzazioni di ambienti benefici," TECHNE: Journal of Technology for Architecture \& Environment, vol. 9, 2015.

[28] "Horticultural therapy: the 'healing garden' and gardening in rehabilitation measures atDanderyd Hospital Rehabilitation Clinic"," Sweden. Pediatric. Rehabil, vol. 7, no. 4, pp. 245-260, 2004.

[29] C. Erbino, A. Toccolini, I. Vagge, and P. S. Ferrario, "Guidelines for the design of a healing garden for the rehabilitation of psychiatric patients," Journal of Agricultural Engineering, vol. 46, no. 2, pp. 43-51, 2015.

[30] S. Whitehouse et al., "Evaluating a children's hospital garden environment: Utilization and consumer satisfaction," J. Environ. Psychol., vol. 21, no. 3, pp. 301-314, 2001

[31] S. A. Sherman, J. W. Varni, R. S. Ulrich, and V. L. Malcarne, "Postoccupancy evaluation of healing gardens in a pediatric cancer center," Landsc. Urban Plan, vol. 73, no. 2-3, pp. 167-183, 2005.

[32] S. Pasha and M. M. Shepley, "Research note: Physical activity in pediatric healing gardens," Landsc. Urban Plan, vol. 118, pp. 53-58, 2013.

[33] N. A. Sachs, "Gardens in healthcare facilities: Steps toward evaluation and certification," World Health Design, vol. 6, no. 6, pp. 76-83, 2013.

[34] M. P. Déjeant, "The European landscape convention," Landscape Research, vol. 31, no. 4, pp. 363-384, 2006. 